\title{
Organizational Culture and Its Corporate Image: A Model Juxtaposition
}

\author{
Obasan, Kehinde. A \\ Department of Business Administration \\ Olabisi Onabanjo University \\ Ago-Iwoye, Nigeria \\ Tel: 234-805-6141-961Ｅ-mail: obasankehinde@yahoo.com
}

Received: December 18, 2011

Accepted: January 5, $2012 \quad$ Published: March 1, 2012

doi:10.5430/bmr.v1n1p121

URL: http://dx.doi.org/10.5430/bmr.v1n1p121

\begin{abstract}
In this 21 st century, the advent of globalization forced most organizations to compete for material inputs, partners, customers and market share, but without a prior knowledge and application of strategically laid path and the establishment of critical factors that justify success in these areas the survival and relevance of such organization is threatened.

Today, observations from the general public and reports from media have it that every day, highly reputable organizations swim in huge debts to banks and co-players. The economic pressures, challenges and market competition have sent some organizations packing out of the market scene and probably get them reduced to almost nothing.

In light of the above, this study tends to believe that the management team players of organizations are ignorant of the effective role and impact of organizational culture and its corporate image play on the organization's capacity, effectiveness, productivity and longevity, and as a result, presents an empirical juxtaposition between the structure of an organization and its corporate image.

It was observed that four main factors influence organizational culture while corporate image and organizational culture are of major concerns that have a direct impact on the level of organizational success through marketing and management efforts as well as organization's longevity, productivity, effectiveness and efficiency.

Hence, it is recommended that management team players and executives need to understand the pivotal roles of organizational culture and its corporate image as foundations for profit-making, productivity and progress so that proper measure can be taken towards adjustment.
\end{abstract}

Keywords: Organization culture, Corporate image, Branding, Behaviour

\section{Introduction}

In the past 25 years, the concept of organizational culture has gained wide acceptance as a way to understand human systems. Increased competition, globalization, mergers, acquisitions, alliances, and various workforce departments have created a greater need for organizational culture. Thus, it has become an important pattern for the organization's development.

Organizational culture is a powerful component of an organization's success, laying the tracks for strategy to roll out on. It is the foundation for profit, productivity and progress. Each aspect of organizational culture can be seen as an important environmental condition affecting the system and its subsystems.

As a result, the actions of employees such as service personnel are seen as being important in communicating a company's corporate values and goals, particularly where they interact directly with customers and other corporate audiences. Their beliefs, norms and values derived from the organizational culture influence their actions and the informal messages that they communicate. This in turn, determines how their company is perceived, what it stands for, as well as the value of its products. This goes a long way to affecting the corporate image of the organization and makes it evident that there is a strong positive correlation between people's perceptions of a company (corporate image) and pro-corporate supportive behaviour (organizational behaviour).

In view of the above, effective Organizational culture and corporate image management become critical for companies to strategically manage their reputation in a way that preserve their integrity and credibility Handelman (2006). Hence, this study presents an empirical juxtaposition between organizational culture and corporate image by identifying the need for 
organizational development strategy at various departments, so as to improve the company's culture and in turns its corporate image. Also, It presents a conceptual framework for the design and implementation of an organizational development strategy.

\section{Literature Review}

\subsection{Organizational Culture}

Organizational culture is an idea in the field of Organizational studies and management which describes the psychology, attitudes, experiences, beliefs and values (personal and cultural values) of an organization. Organizational culture has been defined as the "normative glue" that holds an organization together (Tichy 1982). Forehand and von Gilmer (1964) suggest that culture is the set of characteristics that describe an organization and distinguish it from others. Schein (1990), in a more comprehensive fashion, defines culture as values and behaviours that are believed to lead to success and are thus taught to new members.

The contemporary definition of Organizational Culture includes what is valued; the leadership style, the language and symbols, the procedures and routines, and the definitions of success that characterizes an organization. It is a specific collection of values and norms that are shared by people and groups in an organization and that control the way they interact with each other and with stakeholders outside the organization.

Here, organizational values are beliefs and ideas, about, what kinds of goals members of an organization should pursue and the appropriate kinds or standards of behaviour organizational members should use to achieve these goals. From organizational values develops organizational norms, guidelines or expectations that prescribe appropriate kinds of behaviour by employees in particular situations and control the behaviour of organizational members towards one another.

Central to the culture definition is the idea that culture must be learned and shared (Titiev, 1959). This learned and shared component begins to address the cognitive process that leads to individual decision making and behaviour. Organizational culture maintains influence over its members through the development of values acceptable to the organization. Organizational culture has primarily been viewed as an internal phenomenon, having an impact on staff behaviour and attitudes, and ultimately influencing organizational performance. Yet, it has more recently been conceptualized as a factor in shaping a company's image in the marketplace.

At the deeper and less visible level, organizational culture refers to values that are shared by the people in a group and that tend to persist over time even when group membership changes. At the more visible level, organizational culture represents the behaviour patterns or style of an organization that new employees are automatically encouraged to follow by their fellow employees. Each level of culture has a tendency to influence the other Kotter and Heskett (1992). These definitions outline some of the common key elements that appear in many of the definitions proposed for organizational culture. First, organizational culture is a shared phenomenon (see Tichy, 1982; Pfeffer, 1981; Wilkins and Ouchi, 1983).

Organizational culture, in this sense, is a learned product of group experience and is, therefore, only to be found where there is a definable group with a significant history. The group does not necessarily have to be a whole company. Companies can have multiple cultures (Kotter and Heskett, 1992) or subcultures (Wilson, 1997) usually associated with different functional or geographic groupings.

Second, the majority of authors, with the exception of Schein (1991), believe that there are two levels of culture, the visible level and the deeper, less visible level. Schein's (1990) view is that the term organizational culture should only relate to the "deeper" less visible level, although he does use visible evidence to understand and describe different cultures. The visible aspects encompass behaviour patterns, the physical and social environment and the written and spoken language used by the group. Many of these have been researched using a semiotic approach by researchers such as Barley (1983), Manning (1979) and Van Maanen (1977).

The deeper, less visible level of culture relates to the group's values and what Schein (1991) calls their basic assumptions. The shared values consist of the goals and concerns that shape a group's sense of what "ought" to be. These notions, about acceptable norms, values and behaviour, can vary greatly in different groups; in some settings people care deeply about money, in others about customer well-being or employee well-being.

From a marketing perspective, some of these values may remain conscious and may be explicitly stated in a company's mission statement as the "dominant values of the organization" (Deal and Kennedy, 1982).

However, if these values are not based on prior cultural learning they may also come to be seen only as what Argyris and Schon (1978) have called "espoused values", which predict what people will say in a variety of situations but which may be out of line with what they will actually do in situations where those values should be operating. Therefore the company's corporate marketing activity may say something about commitment to serving the customer, but its record in 
that regard may contradict what it says. Therefore the underlying values, assumptions and beliefs of organizational culture are more than simply strategic priorities and goals.

The third element relates to the manner in which new members learn the culture. A process of cultural socialization arises informally from the existing employees and formally through induction training programmes. Harrison and Carroll (1991) explained that if an individual enters an organization where employees work in an environment of strong group and peer pressure, the individual adopts the employees' norms. Whereas when the group pressures are weak, the individual is likely to accept the norms encouraged by management. There is therefore no guarantee that the service personnel interacting with customers will adopt or communicate the content of the internal corporate marketing messages.

Furthermore, organizational cultures tend to change slowly over time. Kotter and Heskett (1992) explained that culture evolves as a result of the turnover of group members, changes in the company's market environment and general changes in society. Wilkins and Ouchi (1983) quoted a number of examples of organizations claiming to experience great distress because the culture could not be changed or because its members would not change fast enough.

Developing these elements into a definition results in organizational culture being defined as the visible and less visible norms, values and behaviour that are shared by a group of employees which shape the group's sense of what is acceptable and valid. These are generally slow to change and new group members learn them through both an informal and formal socialization process.

\subsection{The Nature of Organizational Culture}

To fully understand the nature of the organizational culture, it is necessary to explore the various perspectives of culture that have been adopted by the organizational behaviourists and other researchers in this field. Martin and Meyerson (1988) identified the following three major perspectives in organizational culture.

1) The integration perspective

This portrays a strong or desirable culture as one where there is organization-wide consensus and consistency (Schein, 1991; Barley, 1983; Deal and Kennedy, 1982; Peters and Waterman, 1982). Espoused values are consistent with formal practices, which are consistent with informal beliefs, norms and attitudes. Cultural members share the same values, promoting a shared sense of loyalty and commitment. Where inconsistencies, conflict or subcultural differentiation occur, this is portrayed as being a weak or negative culture.

\section{2) The differentiation perspective}

This emphasizes that rather than consensus being organization-wide, it only occurs within the boundaries of a subculture. At the organizational level, differentiated subcultures may co-exist in harmony, conflict or indifference to each other. Van Maanen (1991), in his study of Disneyland found groups of employees who considered themselves as being distinct. These sub-cultures related to different jobs, different levels of organizational status gender and class. Claims of harmony from management masked a range of inconsistencies and group antagonisms. Wilson (1997), in his examination of a bank, found a nested set of subcultures, the dominant influence being the service delivery team followed by the hierarchical status of the employees. What is unique about a given organization's culture, then, is the particular mix of subcultural differences within an organization's boundaries.

\section{3) The fragmentation perspective}

This approach views ambiguity as the norm, with consensus and dissension co-existing in a constantly fluctuating pattern influenced by events and specific areas of decision making. As stated by Frost et al. (1991), consensus fails to coalesce on an organization-wide or subcultural basis, except in transient, issue-specific ways. Rather than the clear unity of the integration perspective, or the clear conflicts of the differentiation viewpoint, fragmentation focuses on that which is unclear.

Martin and Meyerson (1988) also argued that any culture contains elements that can be understood only when all three perspectives are used. However, there are methodological limitation in the three perspectives as observed by peters and Waterina (1982); Deal and Kennedy (1982); Barley(1983); Martin and Meyerson argue that from a senior manager's/director's point of view, the integrationist perspective may be congruent with a manager's desire to see their values and policies shared and followed. Middle management may want to distance itself from senior management and therefore subcultures and a differentiation perspective may be more appropriate. Newcomers and disenchanted shop floor workers may fit in more with the fragmentation perspective.

Therefore, within a company there may be organization-wide consensus on some issues, consensus only within certain subcultures on other issues and an ambiguous state on the remainder. Schein, in Frost et al (1991), suggested that there may be a core set of ideological guidelines within an organization that require a minimal consensus and consistency, 
otherwise organizations would not function. Therefore consistency, consensus, harmony and integration may occur, but within the midst of inconsistencies, ambiguities, conflicts, disruption and dissolution.

\subsection{Factors Influencing Organizational Culture}

In assessing the nature of an organization's culture, it is important for stakeholders, managers, company executives and marketers to understand the factors which underpin and influence organizational culture. The most frequently cited groupings of factors (Schein, 1991) include the following.

1) The business environment

The general business environment in which an organization operates helps to determine the culture. Society at large will influence opinions about work, money, status and different types of jobs. The writings of sociology and anthropology highlight the differences in cultural attitudes between geographical regions as well as differences between different levels of social strata. These differences will affect commitment, respect for managers, attitudes towards service and the customer.

Banks and bankers have a risk-averse nature, whereas stockbrokers have a deal-oriented culture. These societal aspects provide the foundations upon which the corporate culture is developed (Normann, 1991, p. 164).

Many of the companies who have had greatest need for a culture change have been those who have lost their monopolistic position (privatised companies such as British Telecom) or where an industry-wide cartel had broken down (ICI) as the non-competitive market environment had impacted on employees and their attitudes (Drennan, 1992).

2) Leadership

Leadership is thought by authors such as Kotter and Heskett (1992) and Schein (1983) as having some influence on the culture of an organization. However, there is no empirical evidence to suggest that it has the totally overpowering and guiding hand suggested by these authors.

Where there is evidence of a link between leadership and culture, it is in young newly created organizations. In new organizations, Pettigrew (1979) believes that the entrepreneur or founder influences the culture through his own ambitions, the interactive processes between entrepreneurs and their followers and the more general processes through which purpose and commitment are generated and sustained. Schein (1991) saw the founder as having a critical role in reducing anxiety within a new group situation. As the founder's prescriptions of how things are to be done help to set standards of acceptable behaviour and best practice, they also help to structure the initially unstructured relationships among the new group members.

If the founder is surrounded by colleagues and employees who are not willing to accept his initial assumptions, the process of culture development will involve conflict, negotiation, compromise, and in some cases, the removal of members from the group. Because of the power of a founder, the emerging culture may then reflect not only the founder's assumptions, but the complex internal accommodations created by subordinates to run the organization "in spite of" or "around" the leader. When the founder steps down or dies, his or her successor is often faced with intransigence if there is a desire to change things in response to new circumstances. This may be due to the influence and respect given to the previous leader or it may be due simply to people's general inertia and unwillingness to change.

3) Management practices and the formal socialization process

The manner in which a company is managed is likely to influence either positively or negatively the beliefs, attitudes and behaviour of the employees. Before considering management practices, there is a need to distinguish between management and leadership. Kotter (1990) summarized many authors' definitions of leadership by stating that it is involved in the long-term direction of the company through the development of a vision and strategies for the future. The leader is then responsible for communicating through words and deeds this vision to internal and external audiences while motivating and inspiring the individuals who have to deliver it. Management, on the other hand, is generally described as being about the detailed planning, budgeting, organizing, controlling and staffing of the organization as well as ad hoc problem solving.

Within these management tasks, managers have control over a range of factors that apparently affect cultural transmission. The most important of these, highlighted by Harrison and Carrol (1991), are recruitment, formal socialization procedures and the turnover of employees.

The types of people recruited can help to perpetuate a cultural orientation as recruiters will tend to find attractive those candidates who resemble present members in style, assumptions, values and beliefs. This form of cultural embedding operates unconsciously in most organizations. 
The design of the organization with its hierarchies and reporting structures is also seen as having an impact on the norms and values of individuals at different points within it (Schein, 1991). Harrison and Carroll (1991) consider the impact of different organizational forms, such as Japanese-style, governmental-bureaucratic form and collectivist-democratic form in their cultural transmission model. The findings are relatively inconclusive and tend to reflect national traits (e.g. the Japanese providing a stable corporate culture) rather than the design of the organization. However, aspects such as decentralization, empowerment of employees and recognition of unions all seem to have an impact on the elements of corporate culture.

4) The informal socialization process

As all of the definitions of corporate culture identify the critical element of sharing within a group, it is important to consider how an individual behaves within the group context. From group dynamic theory, the individual in a group setting has basically three primary needs (Schein, 1969, 1991; Schutz, 1969; McGrath, 1984).

The first of these is to feel part of the group by developing a viable role and being recognized by other members of the group. This involves a compromise of maintaining a distinct and separate identity at the same time as being seen as a group member.

Second, there is a need to feel powerful, able to influence and control whilst accepting the needs of others to do the same. This can lead to conflict but can also help to formulate the roles of individuals within the group.

Third, there is a need to feel accepted by the group and to achieve the basic security and intimacy that comes with that.

These factors are important whether it is a totally new group that is being formed or where a new member is entering an existing group. Schein (1991) saw these needs as reflecting the basic human needs for security, mastery of the environment (influence and control) and love (acceptance and intimacy).

As a result of efforts to stabilize these needs and the personalities of the different group members, norms and standards arise and, ultimately, are consensually accepted and enforced. A long-term mutual supportive relationship between an Organization's strategic vision and culture appears as the groundwork for the development of a successful and authentic corporate brand. Our integrative model suggests that coherent interplays between strategic vision and Organizational culture happen through the development of consistent Organization's intended image and identity.

Organizational culture represents the tacit Organizational understanding (e.g. beliefs, values and norms) that contextualizes efforts of Organization's members to make meaning, including internal collective self-definition (Hatch and Schultz, 2002). It therefore provides a context for the formation of identities in Organizations Ravasi and Schultz (2006). By contrast, Organizational identity is more concerned with how Organization's members express cultural values and develop a collective self-definition of the Organization based on its central, enduring and distinctive attributes. As such, Organizational identity intrinsically constitutes an indispensable reference point to help senior management to apprehend the values, beliefs and norms characterizing their Organizational culture.

This socialization process is supported by the telling of what has been termed myths, stories and legends (Schall, 1981; Meyer, 1981; Cohen, 1975; Martin and Powers, 1983; Schein, 1991) about specific situations and how they were handled (i.e. why certain people were sacked and why some were promoted). This reinforces patterns of acceptable and unacceptable behaviour, and it can also become a means of spreading a counter-culture or of revealing inconsistencies or absurdities in the main culture.

\subsection{Organizational Culture Change}

The culture of a group does evolve and change over time as a result of changes in the various influencing factors. However, the influencing factors and components of organizational culture are complex and intertwined. As a result, these evolutionary changes may be too slow for the market and the management. The question then arises as to whether changes in an organization's culture or cultures can be managed.

Some researchers question whether organizational culture is indeed manageable because of the existence of subcultures, or even countercultures competing to define the nature of situations within organizational boundaries (Smircich, 1983). As stated by Bryman (1984), no one genuinely seems to argue that cultures are absolutely inert and incapable of new directions. However, there is controversy over the degree of ease with which change can be introduced and managed.

There is also a debate as to whether the popular texts actually relate to culture or whether they simply relate to strategic directions and structures. Many of the changes discussed and championed as successful culture changes relate to improved entrepreneurship, the adoption of a customer or market orientation, teamwork or a financial discipline. Bryman (1984) described such orientations as superficial indicators of cultures, that would have been subsumed under umbrella terms like structure or strategy had culture not become so fashionable in recent years. Changes in the underlying values and norms 
that determine behaviour may not change and what companies may witness is merely behavioural compliance. As a result, the implied benefits of the adoption of such orientations may be short-lived.

As stated by Schein (1991), culture operates as a set of implicit assumptions, which cannot change unless they are brought to the surface and confronted. Therefore change may come about by getting employees to surface and re-examine the assumptions they hold. The role of management is to identify and manipulate the culture-influencing factors that will motivate employees to re-examine and potentially change their own internal assumptions and values. In addition, managers are part of a company's culture and therefore their own values and assumptions need to be reviewed (Irons, 1993). Overall, managers and their activities may therefore only act as catalysts for change rather than as dictators of change.

Below are important key ingredients of Organizational Culture:

- It focuses attention on the human side of organizational life, and finds significance and learning in even its most ordinary aspects.

- It clarifies the importance of creating appropriate systems of shared meaning to help people work together toward desired outcomes.

- It requires members especially leaders, to acknowledge the impact of their behaviour on the organization's culture.

- It encourages the view that the perceived relationship between an organization and its environment is also affected by the organization's basic assumptions.

- Organizational Culture creates energy and momentum. The energy will permeate the organization and create a new momentum for success.

\subsection{Organizational image}

Organization image is the perceptions that different people hold of an organization. Such perceptions can have different sources depending on how well people know the organization. Some perceptions derive from individual experiences and impressions of the organization, while others are influenced by the marketing and communication activities seeking to influence the image of the organization. Image is important for an organizations ability to attract and retain relationships with its different internal and external constituencies.

The concept of organizational image has been used within several disciplines holding slightly different definitions of the concept. As demonstrated by Hatch and Schultz (1997) in 'The expressive organization' from 2000 organizational image differs between marketing and organization studies, although image in general concerns perceptions held by multiple external 'others' of the organization. Kevin (2000) shows the organizational associations that are considered to be particularly important in the perception of organizational image.

- Common product attributes benefits or attitudes such as quality and innovativeness

- People and relationships such as customer orientation

- Values and programs such as concern with environment and social responsibility

- Corporate credibility such as expertise, trustworthiness and likability.

Some have used the concept of corporate branding to conceptualize the role of organizational image seen in relation to the identity, culture and vision of organizations. Hatch and Schultz (2003) advocate the potential of corporate branding to attract stakeholders and encourage them to feel a sense of belonging with the Organization; they do not specifically refer to the related concept of organizational identification Dutton et al., (1994) which however constitutes a powerful and measurable proxy for corporate branding performance. All of these new developments share a number of insights for the further elaboration of organizational image

First of all, the importance of organizational image has increased. Outsiders have higher expectations about transparency and organizations' ability to express who they are and what they stand for; just as insiders pay more attention to how outsiders perceive their organization. At the same time, the value creation in organizations is increasingly depending on intangibles, where the unique heritage and identity of the organization is part of what enables the organization to create an organizational image, which is appealing to stakeholders.

Secondly, the construct of organizational image is developed in close interrelationship with other constructs such as organizational identity, organizational culture, corporate branding and corporate reputation. 
Thirdly, a holistic conceptualization of organizational image implies that studying organizational image requires a cross-disciplinary effort drawing on organization studies, marketing, corporate communications and strategy.

Within marketing, image has been used to analyze how consumers perceive the organization and its products and services. The conceptualization of image focuses on how different segments of consumers form perceptions of the organization and how they influence their relationship with the organization. Thus, an organizational image often differs across national cultures, social groupings or people with different attitudes towards life. Marketing scholars have developed elaborate methods and measurements to study image perceptions, such as the various types of associations that follow from different images or the relevance and emotional bonding that follow from a positive or negative image. When studying images at the organizational level, marketers such as Philip Kotler and Stephen Greyser talk about corporate image and use image marketing as the concept for how organizations seek to influence the perceptions of the organization. The basic assumption is that an image adds value to the organization by creating positive perceptions of how the organization is different from and better than others.

Within organization studies organizational image has been subject to different conceptualizations and debates. Most importantly, many organizational scholars take organizational image to be organizational members' perceptions of how outsiders perceive the organization. The focus of organizational image shifts from 'how others perceive the organization' to 'how we perceive that others perceive the organization'. In their paper on 'Adaptive Instability' Gioia, Schulz and Corley (1998) provide an overview of the different definitions of organizational image used within organization studies. In general, the definition of external construed image has been taken to be organizational image within organizational studies, whereas organizational image within marketing has been defined as corporate image.

For the purpose of this study, we shall consider only corporate image.

\subsection{Corporate Image}

Corporate image refers to how a corporation is perceived. It is a generally accepted image of what a company stands for. The creation of a corporate image is an exercise in perception management. It is created primarily by marketing experts who use public relations and other forms of promotion to suggest a mental picture to the public. Typically, a corporate image is designed to be appealing to the public, so that the company can spark an interest among consumers, create share of mind, generate brand equity, and thus facilitate product sales (Wikipedia, the free encyclopedia).

The Corporate image is a dynamic and profound affirmation of the nature, culture and structure of an organization. This applies equally to corporations, businesses, government entities, and non-profit organizations. The corporate image communicates the organization's mission, the professionalism of its leadership, the caliber of its employees and its roles within the marketing environment or political landscape.

Every organization has a corporate image, whether it wants one or not. When properly designed and managed, the corporate image will accurately reflect the level of the organization's commitment to quality, excellence and relationships with its various constituents - including current and potential customers, employees and future staff, competitors, partners, governing bodies, and the general public at large.

The Corporate image comprises all the visual, verbal and behavioural elements that make up the organization. In many respects, the corporate image should be a dynamic actualization of the Chief Executive Officer's vision, integrated with the corporation's mission and strategic plan. It should be thoroughly planned and constantly managed in order to support and sustain the corporation's mission. If managed effectively, it should protect the organization against competition from new competitors or from current competitors offering new products and services. Unfortunately, this is usually not the case.

The corporate identity is the visual representation of the company and should not be confused with the corporate image. This visual representation usually takes the form of a corporate signature and a corporate symbol or logo. These distinguish graphically the corporation from its competitors, and positions the enterprise visually in the global marketplace through a consistent use of typeface, color palette and logo identifier.

Previously, the company's visual identity system was sufficient to project and protect the image of the organization. Today, all aspects of the corporate image need to be managed, from the refinement of the mission statement to how well the troops on the front-line understand, communicate and portray this mission.

\subsection{Corporate Image Management}

Management of the corporateimage integrates the corporate culture with the process of managing and it requires the best leadership, communication and training skills the organization can muster. 
Corporate image management entails the creation of a corporate language, behaviour patterns, symbology, traditions and a dialog that focus on an appropriate expression of the company. This dialog matches the expectations and understanding of both customers and employees about what the organization stands for, where it is heading and what its core strengths, traditions and principles are. It also develops relevance within every single aspect of the company, its products and its services, and results in perceptions that become the key to long term success. In a way, corporate image management is the purest definition of total quality management: if everything has relevance to the company or to its customers, then nothing retained is wastage.

Corporate image management focuses on the very heart and soul of the organization, even to the extent of evaluating why the organization exists and determining the organization's key purposes. It represents one of the highest levels of functional control of the organization.

Perhaps more importantly, its value as a management tool is greater because it provides a mechanism for the organization to:

- differentiate itself from competition,

- create recognized added- value to the products and services marketed or delivered by the organization, and

- attract and maintain customer relationships in order to prosper in an increasingly competitive and constantly changing global marketplace.

Corporate image management, therefore, also represents the highest level of brand personality and characteristics that can be created and communicated to customers and marketing partners.

\subsection{Organizational Culture and Its Corporate Image}

One of the major communicative challenges facing the modern corporation is the need to communicate its identity and its values in order to distinguish itself from competitors and to promote the corporate brand in a highly competitive and international business context in which branding becomes increasingly important. Hatch \& Schultz (2009). The culture of an organization shapes its corporate image both for its internal and external customers. It also contributes significantly to the organization's brand image and brand promise. Organizational culture is known as the values, beliefs and basic assumptions that are guided by leaders and shared by employees, and that explain "how things are done around here." Organizational culture has primarily been viewed as an internal phenomenon, having an impact on staff behaviour and attitudes, and ultimately influencing organizational performance. Yet, it has more recently been conceptualized as a factor in shaping a company's image in the marketplace. Corporate image is an overall perception of the company held by different segments of the public (Villanova, Zinkhan and Hyman, 1990).

The two key phrases in the definition "overall perception" and "different segments," indicate that corporate image is more than a mere sum of the impressions of individual attributes and that it encompasses all of the company functions and roles. Corporate image includes information and inferences about the company as an employer, as a seller, as an investment and as a corporate citizen. A company will have more than one image depending on the nature of the interaction it has with the different groups. Since people tend to "humanize" companies (Bayton, 1959), corporate image may also include characteristics often attributed to humans such as "caring", "friendly", and "ruthless" and so on.

The public segments which corporations are most concerned with are their stakeholder groups. Each major stakeholder group has different characteristics, needs and expectations and may hold a different image of a company.

Also, the increasing demand in society for authenticity and transparency in the business world in general requires the corporation to speak with one, identifiable voice Christensen \&Morsing, (2008), while at the same time addressing groups of multiple stakeholders with potentially different or conflicting agendas. Shelley (2005) disclosed that organizations' relations with stakeholders constitute a prominent feature of organizational identity, that relations with external and internal stakeholders are perceived as tightly coupled, that both pure and hybrid identity orientation types are relatively common, and that identity orientation varies widely among business organizations. A strong corporate identity and a clear internal awareness of "who we are and what we stand for" Hatch \& Schultz (2000) depend on a successful and balanced interplay between corporate image, corporate culture and corporate vision. In brand related narratives, the question of identity is reflected at different levels.

\section{Methodology}

The study adopted a qualitative research design by reviewing and integrating previous findings and researches on organizational culture and corporate image. Also, interviews were conducted with company owners and executive officers to identify the basic challenges facing them. Six major variables are identified based on present discoveries from previous researches and were adopted by this study to model the organizational culture. They include knowledge and skills, 
performance capacity, motivation and self-concept, tools, environment and processes, expectation and feedback, rewards, recognition and incentives. The formulated model assumes a corporate image as one of the organization's resources.

Then, it goes further to enumerate core objects that make up the model which once implemented correctly ensures significant accomplishment and these include; the organizational resources, the basic understanding of the organization's vision, mission and objectives at all departmental levels, coupled with a strong organizational culture. The model is presented in figure 1

\section{Discussion of Results}

This result of this study suggests that a significant accomplishment can only be achieved by a collaborative effort of core objects of determinant which include: the organization's resources, shared vision, mission and objectives cycling around its corporate image coupled with a strong organizational culture which stands as the support system. Knowledge and skills, performance capacity, motivation and self-concept, tools, environment and processes, expectation and feedback, rewards, recognition and incentives are basic ingredients of a good organizational culture. Vision, Resources, and Support System must be in place and aligned with each other.

The interviews conducted for company owners and executive officers revealed that they faced various challenges in the promotion and preservation of the corporate image and culture. These challenges vary from one organization to another but the totality of these challenges borne out of the stakeholders permeating and porous organizational culture and corporate image. As a result, core objects of an organization's optimum performance are harnessed. This led to the formulation of a model approach for the design and implementation of an organizational development strategy which enhances understanding of the nature and scope of corporate image and organizational culture and how they can be harnessed, utilized and applied.

The Organization support system includes six major components and recognizes the influence of organizational culture and corporate image on performance.

The principles that govern these core objects and the basic constituents of a good organizational culture have been explicitly examined in the course of this study. The proposed model approach is designed to represent the organizational development strategy which in turn is expected to result to goals attainments such as:

a) Stimulate sales;

b) Establish company's goodwill;

c) Create an identity for employees;

d) Influence investors and financial institutions;

e) Promote favorable relations with the community, government, special interest groups and other opinion leaders;

f) Achieve a competitive position; and

g) Make profits and other significant accomplishments.

\section{Conclusion}

This study reveals that organizational culture does have a positive effect on employee attitudes, organization's capacity, effectiveness, productivity and longevity. It clarifies the importance of creating appropriate systems of shared meaning to help people work together toward desired outcomes. It requires members especially leaders, to acknowledge the impact of their behaviour and attitude on the organization's culture.

It encourages the view that the perceived relationship between an organization and its environment is also affected by the organization's basic assumptions.

The above-mentioned relevance of organizational culture supports the proposition that, in this competitive and globalized corporate scenario, there is huge need for organizational development strategy at various workforce departments, as this can improve the company's culture. Thus, to fulfill organizations development needs, a framework presented in this study can be adopted for a more significant output.

A strong organizational culture creates a feeling of belonging and increases job satisfaction and commitment. One of the most effective ways for companies to accomplish this is through their employee training. Training is obviously used to impart the knowledge, skills, and abilities needed to successfully meet the company's objectives. 


\section{Recommendations}

As evident from this study, It is recommended that a coherent corporate image needs to be integrated into the organization at all levels and also, a basic understanding of the kinds of goals members of an organization should pursue and ideas about the appropriate kinds or standards of behaviour organizational members should use to achieve these goals is required and must be place on a top-priority list. Management must also accept the responsibility of not only sharing the values and behaviours suggested by the organizational culture but also embodying these same values and behaviours since it is folly to expect employees' adherence to values and behaviours that are ignored by management. Management should also understand that it possesses the opportunity to create, influence, and utilize these positive effects that can result from a strong organizational culture.

\section{References}

Ajzen, I. \&Fishbein, M. (1980). Understanding Attitudes and Predicting Social Behaviour. Englewood Cliffs, NJ: Prentice Hall.

Albert, S. and Whetten, D.A. (1985). Organizational identity. In L.L. Cummings and M.M. Staw (eds.) Research in Organizational Behaviour, 7: 263-295.

Alessandrini, S. W. (2001). Modeling corporate identity: A concept explication and theoretical explanation.Corporate Communications, 6(4): 173-183. http://dx.doi.org/10.1108/EUM0000000006146

Albert, S. et al. (1998). Identification with organizations. In Whetten, D. and Godfrey, P. (eds.) Identity in Organizations. Building theory through conversations. Thousands Oaks.Sage Publications. 209 - 273.

Alvesson, M. (2002). Understanding Organizational Culture, Sage, London, Thousand Oaks, New Delhi.

Appadurai, A. (1998). Modernity at Large, University of Minnesota Press, Minneapolis.

Ashforth, B.E. and Mael, F. (1989). Social identity theory and the organization. Academy of Management Review, 14: $20-39$.

Atkinson, R. C. \&Juola, J. F. (1973). Factors influencing speed and accuracy of word recognition.in Attention and Special Performance IV, S. Kornblum, ed.New York: Academic Press.

Augé, M. (1995). Non-places: Introduction to and Anthropology of Supermodernity, Verso, London.

Beaumont, P. B. (1996). Human Resource Management: Key Concept and Skills, Sage, London.

Bennett, N. (2003). Structure, culture and power in Organizations, in: Effective Educational Leadership. Ed.: Bennett N., Crawford, M. \& Cartwright M. London: Paul Chapman Publishing.

Bhabha, H. K. (1994). Locations of Culture,.Routlege, London, New York.

Black, Richard J. (2003). Organizational Culture: Creating the Influence Needed for Strategic Success, London UK, ISBN 1-58112-211-X

Bligh, Michelle C. (2006). "Surviving Post-merger 'Culture Clash': Can Cultural Leadership Lessen the Casualties?" Leadership, vol. 2: pp. 395 - 426. http://dx.doi.org/10.1177/1742715006068937

Baker, M.J. \&Balmer, J.M.T. (1997). Visual Identity: Trappings or substance. European Journal of Marketing, 31(5/6): 366-375. http://dx.doi.org/10.1108/eb060637

Balmer, J.M.T. (1994). The BBC's corporate identity: Myth, paradox and reality. Journal of General Management, 19(3): 33-49.

Balmer, J.M.T. (2001). Corporate identity, corporate branding and corporate marketing - Seeing through the fog.European Journal of Marketing, 35(3/4): 248-270. http://dx.doi.org/10.1108/03090560110694763

Balmer, J.M.T. \&Dinnie, K. 1999. Corporate identity and corporate communications: The antidote to merger madness. Corporate Communications, 4(4): 182-194. http://dx.doi.org/10.1108/13563289910299300

Bauman, Z. (1992). Intimations of postmodernity. London: Routledge.

Christensen, L. Th. \&Morsing, M. (2008). Bagom corporate communication. Frederiksberg. Samfundslitteratur.

Cummings, Thomas G. \& Worley, Christopher G. (2005). Organization Development and Change, 8th Ed., Thomson South-Western, USA, ISBN 0324260601

Harris, Stanley G. (1994). "Organizational Culture and Individual Sensemaking: A Schema-Based Perspective." Organization Science, Vol. 5,(3): pp. 309-321. http://dx.doi.org/10.1287/orsc.5.3.309 
Hatch, M. J. \& Schultz, M. (1997). Relations between organizational culture, identity and image. European Journal of Marketing, 31(5/6), 356. http://dx.doi.org/10.1108/eb060636

Hatch, M.J. \& Schultz, M. (2000). Scaling the Tower of Babel: Relational Differences between Identity, Image, and Culture in Organizations. In Schultz, M. et al (eds): The Expressive Organization: Linking Identity, Reputation, and the Corporate Brand. Oxford University Press.

Hatch, M.J. and Schultz, M. (2002). The dynamics of organizational identity. Human Relations, Vol. 55 No. 8, pp. 989-18. http://dx.doi.org/10.1177/0018726702055008181

Hatch, M.J. \& Schultz, M. (2009). Brugdit brand.Gyldendal Business. Copenhagen.

Henderson, P. W., \& Cote, J. A. (1998). Guidelines for selecting and modifying logos. Journal of Marketing, 62, April: 14-30. http://dx.doi.org/10.2307/1252158

Henderson, P. W., \& Cote, J. A. (2003). Building strong brands in Asia: Selecting the visual components of image to maximize brand strength. International Journal of Marketing Research, 20: 297-313. http://dx.doi.org/10.1016/j.jiresmar.2003.03.001

Hofstede, G. (1998). 'Attitudes, values and organizational culture: Disentangling the concepts', Organization Studies, 19 (3), 477-492. http://dx.doi.org/10.1177/017084069801900305

Hoyer, W. D. \& Brown, S. P. (1990). Effects of brand awareness on choice for a common, repeat purchase product. Journal of Consumer Research, 17: 141-148. http://dx.doi.org/10.1086/208544

Jacoby, L. L. \& Dallas, M. (1981). On the relationship between autobiographical memory and perceptual learning. Journal of Experimental Psychology, 19(1): 42-46.

Janiszewski, C. \&Meyvis, T. (2001). Effects of brand logo complexity, repetition and spacing on processing fluency and judgement. Journal of Consumer Research, 28(1): 18-32. http://dx.doi.org/10.1086/321945

Kapferer, J.-N. (1997). Strategic Brand Management - Creating and Sustaining Brand Equity Long Term. London: Kogan Page.

Kotter, John. (1992). Corporate Culture and Performance, Free Press; (April 7, 1992) ISBN 0-02-918467-3.

Morgan, G. (1997). Images of Organization, Sage, London, New Delhi.

Morley, D. \& Robins, K. (1995). Spaces of identity, Routledge: London. http://dx.doi.org/10.4324/9780203422977

Pheysey, D. C. (1993). Organizational Cultures: Types and Transformations, Routledge, London.

Ravasi, D., Schultz, M. (2006). "Responding to organizational identity threats: exploring the role of organizational culture", Academy of Management Journal, Vol. 49 No. 3, pp. 433- 58. http://dx.doi.org/10.5465/AMJ.2006.21794663

Rosenau, P. M. (1992). Post-modernism and the social sciences, Princeton University Press, New Jersey.

Seidman, I. (1998). Interviewing as Qualitative Research, Teachers College Press, New York, London.

Schein, E. H. (2004). Organizational culture and leadership, Jossey-Bass, San Francisco.

Shelley L. B. (2005). "Organizational Identity Orientation: Forging a Link between Organizational Identity and Organizations' Relations with Stakeholders" Administrative Science Quarterly Volume: 50, Issue: 4, Pages: 576-609

Stake, R. E. (1995). The Art of Case Study Research, Sage, London.

Stafford, M. R., Tripp, C. \&Bienstock, C. C. (2004). The influence of advertising logo characteristics on audience perceptions of a nonprofit theatrical organization.Journal of Current Issues and Research in Advertising, 26(1): 37- 45.

Stoll, L. (1999). School Culture: Black Hole or Fertile Garden, in: School Culture. Ed.: Prosser, J. London, New Delhi: Sage.

Stuart, H. (1998). Exploring the corporate identity/corporate image interface: An empirical study of accounting firms.Journal of Communication Management, 2(4): 357-371. http://dx.doi.org/10.1108/eb023476

Stuart, H. \&Muzzelec, L. (2004). Corporate makeovers: can hyena be rebranded? Journal of Brand Management, 11(6): 472-483. http://dx.doi.org/10.1057/palgrave.bm.2540193

Van Riel, C.B.M. \&Balmer, J.M.T. (1997). Corporate identity: the concept, its measurement and management. European Journal of Marketing, 31(5/6): 340-355. http://dx.doi.org/10.1108/eb060635 
Table 1. Different forms of organizational image

\begin{tabular}{|l|l|}
\hline Form of image & Definition \\
\hline Corporate image & $\begin{array}{l}\text { The way a company is perceived by all constituents, } \\
\text { often with a strong focus on external constituents }\end{array}$ \\
\hline Construed external image & $\begin{array}{l}\text { Organizational members' perceptions of how outsiders } \\
\text { perceive the organization }\end{array}$ \\
\hline Projected image & $\begin{array}{l}\text { Image created by an organization to be communicated to } \\
\text { constituents; might or might not represent ostensible } \\
\text { reality }\end{array}$ \\
\hline Desired future image & $\begin{array}{l}\text { Visionary perception the organization would like } \\
\text { external others and internal members to have of the } \\
\text { organization sometime in the future }\end{array}$ \\
\hline
\end{tabular}

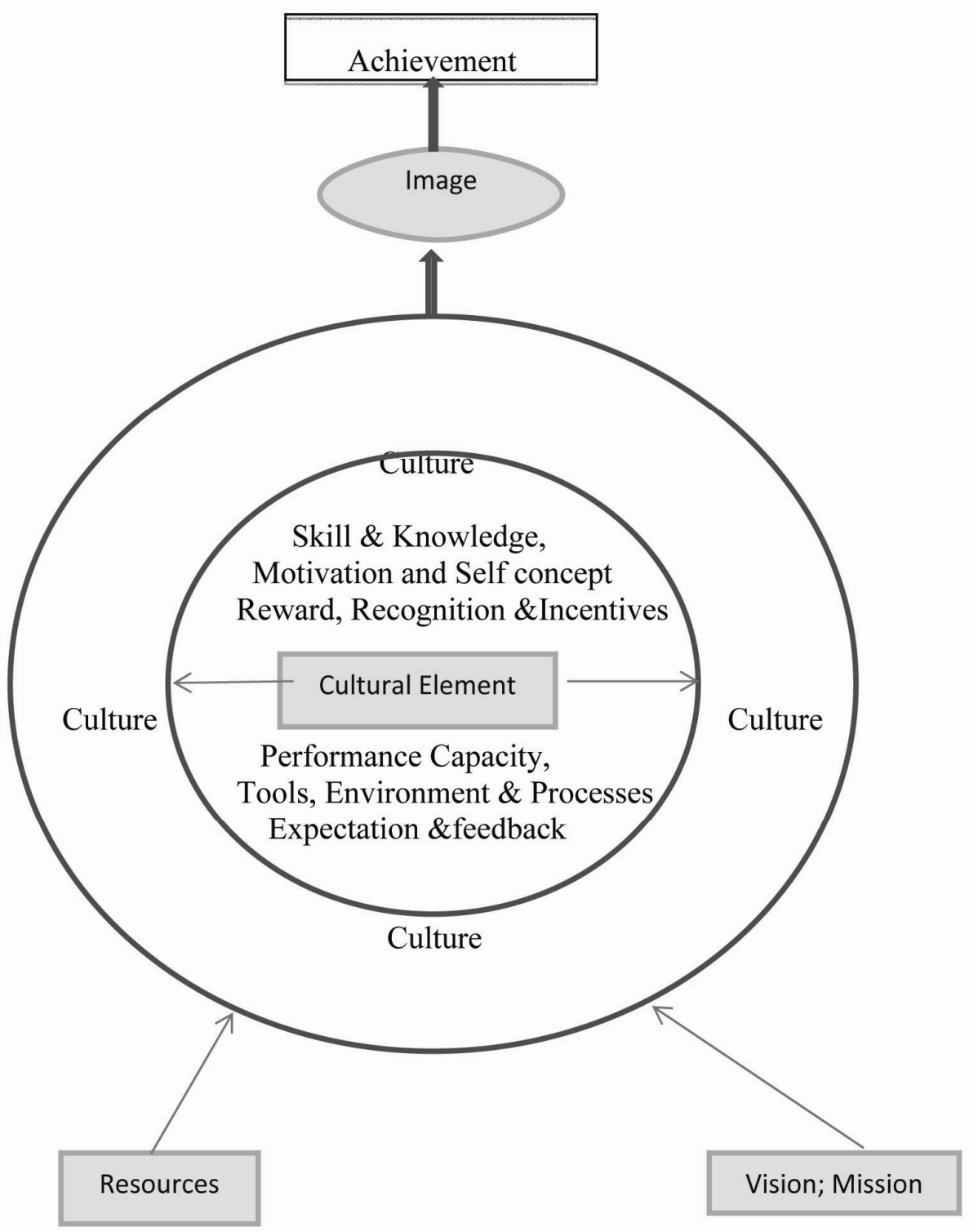

Figure 1. Proposed model approach for an organizational development strategy towards achieving optimum performance 